\title{
A Novel Procedure for Quick Design of Off- Grid PV Water Pumping Systems for Irrigation
}

\author{
Dardan Klimenta ${ }^{1, *}$, Julijana Lekic ${ }^{1}$, Sanela Arsic ${ }^{2}$, Dragan Tasic ${ }^{3}$, Nikola Krstic ${ }^{3}$, \\ Dragana Radosavljevic ${ }^{1}$ \\ ${ }^{1}$ Faculty of Technical Sciences, University of Pristina in Kosovska Mitrovica, \\ Kneza Milosa St. 7, RS-38220 Kosovska Mitrovica, Serbia \\ ${ }^{2}$ Technical Faculty in Bor, University of Belgrade, \\ Vojske Jugoslavije St. 12, RS-19210 Bor, Serbia \\ ${ }^{3}$ Faculty of Electronics Engineering, University of Nis, \\ Aleksandra Medvedeva St. 14, RS-18000 Nis, Serbia \\ dardan.klimenta@pr.ac.rs
}

\begin{abstract}
It is known that meteorological variables from meteorological online services can be used for the design of photovoltaic (PV) water pumping systems for irrigation. The software LORENTZ COMPASS in such a manner uses as inputs solar irradiation, precipitation, and ambient temperature collected by the NASA Langley Research Centre over a period of more than 20 years. This paper proposes a novel procedure that uses the sunshine duration, precipitation, and ambient temperature as inputs. These inputs were collected by Weather Online UK during a period of 25 years. The effects of different data collection periods and data availabilities on the design of the PV water pumping system are also analysed and discussed. Along with the meteorological data, the proposed procedure uses as inputs datasheets from manufacturers of pumping systems and PV modules. The procedure is based on the Sivkov model that correlates the global horizontal irradiation with the sunshine duration and the elevation angle of the Sun. A case study, i.e., an existing PV water pumping system designed using LORENTZ COMPASS is used as reference for purposes of comparison and validation of the procedure. The results of the comparison showed a high level of accuracy, and a number of interesting conclusions are drawn from them.
\end{abstract}

Index Terms-Design procedure; Irrigation; Meteorological variables; Off-grid photovoltaic (PV) water pumping system; Photovoltaic (PV) generator.

\section{INTRODUCTION}

There are a number of procedures, programmes, and software tools for designing photovoltaic (PV) water pumping systems for irrigation. The most famous among them are LORENTZ COMPASS [1], PV DesignPro-P [2], Meteonorm [3], PVsyst [4], DASTPVPS [5], INSEL [5], etc. For most of these software tools, licenses must be purchased, while authorised persons from partner companies can only use some of them. On the other side, there are software tools which do not require any license and which can be used online free of charge, such as

Manuscript received 13 February, 2021; accepted 1 March, 2021.

This research was supported by the Ministry of Education, Science and Technological Development of the Republic of Serbia under Grant No. NIO 200155.
PVSOL [2]. However, such shareware tools have limited capabilities and cannot be used for carrying out the entire design procedure of a PV water pumping system. In all of the cases referred to, the implemented mathematical models, input data collection periods, and input data availabilities are not available for end users. Together with combinations of meteorological variables offered, the data collection periods and data availabilities in meteorological online services differ widely from one to another.

Thus, if historical climate data from meteorological online services are used, it may happen that two software tools generate two different solutions for the same geographical location. This can be seen, e.g., in the fact that the monthly mean values of daily precipitation estimated for the site considered in [1] are between $1.4 \mathrm{~mm}$ and $2.8 \mathrm{~mm}$ throughout the whole year. This estimation was based on the data collected by the NASA Langley Research Centre (www.nasa.gov/langley) over a period of more than 20 years. Based on the data collected by Weather Online UK service (www.weatheronline.co.uk) for the same site over a period of 25 years, this meteorological variable ranges between $1.3 \mathrm{~mm}$ and $3.1 \mathrm{~mm}$. The same applies for any other source of meteorological data [6], such as CM SAF collaboration (www.cmsaf.eu), LSA-SAF collaboration (landsaf.ipma.pt), National Oceanic and Atmospheric Administration (www.noaa.gov/weather), SODA online service (www.soda-is.com), European Centre for Medium Range Weather Forecast (www.ecmwf.int), Weather Online IN service (www.weatheronline.in), World Weather Online service (www.worldweatheronline.com), etc. Therefore, it would be extremely useful to clarify issues of this kind.

The next issue that should be resolved when designing $\mathrm{PV}$ water pumping systems is the accuracy of the estimate for available solar energy in a particular geographic location, and how this estimate affects the final design solution. Software tools, such as PVGIS [6], GRASS GIS [6], and PVMAPS [6], are commonly used for this purpose. In addition, once again, the end users do not have any insight into mathematical models or associated program codes, and thus they cannot in any manner modify the 
models and affect the generated results. In this context, e.g., the values of global horizontal irradiation $(G H I)$ estimated by Ångström-Prescott equation [7], [8] and Sivkov empirical model [9]-[11] will not be equal to each other. This is supported by the fact that there are dozens of different forms of the Ångström-Prescott equation [7], [8] and that Sivkov empirical model is the simplest one, having, compared to similar models, some deviation with regard to the reference experimental data [10], [11]. The deviation of Sivkov empirical model ranges between $4.4 \%$ for lowland areas and $10 \%$ for mountain areas [10], [11], and its possible effect on the rated output powers of PV generators could be introduced by means of some factor. This should be done in a similar manner as in the case of de-rating factors of PV modules for manufacturer's tolerance, dirt/soiling losses, and temperature losses. In addition, it would be interesting to show that this approach is applicable.

This paper aims at exploring all the mentioned issues based on a detailed mathematical procedure for calculating performances of PV water pumping systems for irrigation and its application to a case study example. The proposed procedure consists of a number of known input data, models, equations, conditions, best practices, and engineering details, which are arranged and combined in a novel manner and applied for the first time. This procedure combines a specific set of meteorological variables, datasheets from manufacturers of pumping systems, and PV modules, model correlating the global normal irradiation $(G N I)$ with the global tilted irradiation $(G T I)$, model correlating $G T I$ with $G H I$, Sivkov empirical model for $G H I$, equations for all the PV module/generator performances, conditions concerning the dirt losses based on precipitation, condition concerning the required minimum number of PV modules in one string, condition concerning the number of required strings in one PV generator, etc. Some of these details can be regarded as innovations in the field under consideration.

The proposed procedure is based on the standards IEC 62253 [12], IEC 60891 [13], and IEC 60904 [14] in a similar manner as the procedure used in the software LORENTZ COMPASS. A number of details concerning the different steps of the procedure implemented in LORENTZ COMPASS can be found in [15].

An existing cherry orchard with its PV water pumping system for drip-irrigation, located in Serbia, is selected as the case study on which the proposed procedure will be applied. The second section is dedicated to the case study having a role of the necessary experimental background for this study. In addition, the case study is presented before the mathematical modelling because all data about it are known. The third section deals with the sizing of the PV water pumping system in accordance with the proposed procedure. Furthermore, in the fourth section, the performances of the installed PV water pumping system, which are generated by the software LORENTZ COMPASS, are used for purposes of comparison. This section also presents all the results obtained together with associated discussions. Finally, a number of interesting and useful conclusions are drawn from the presented results, comparisons, and discussions.

\section{CASE Study AND Meteorological Variables}

\section{A. Case Study}

The case study orchard considered in this paper is located in the north-eastern part of Serbia, in the vicinity of the City of Požarevac, that is around $60 \mathrm{~km}$ from the nearest meteorological station Belgrade-Vračar. The meteorological

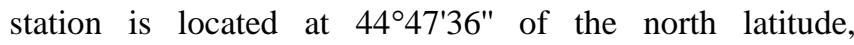
$20^{\circ} 27^{\prime} 23^{\prime \prime}$ of the east longitude, and an elevation of $132 \mathrm{~m}$ above sea level [16]. The City of Požarevac is located at $44^{\circ} 36^{\prime} 50^{\prime \prime}$ of the north latitude, $21^{\circ} 10^{\prime} 14^{\prime \prime}$ of the east longitude, and an elevation of $82 \mathrm{~m}$ above sea level. According to [1], [16], the irrigation season is assumed to be between the beginning of May and the end of August, the maximum value of the monthly optimal inclination $\beta_{o m}$ in the irrigation season is $25^{\circ}$, and the seasonal mean value of daily global normal irradiation $(G N I)$ on a south-oriented surface inclined at $25^{\circ}$ is $5.725 \mathrm{kWh} / \mathrm{m}^{2} /$ day.

The area of the cherry orchard is 3.5 ha and is dripirrigated 24 hours per day during the whole season. A PV generator connected to the pump across the PS2-1800 controller is used for daytime irrigation, while a dieselpowered electric generator connected to the pump across the LORENTZ Power Pack LZ-PP2000/UL AC/DC converter is used for night-time irrigation. Both generators are not connected to the power system. The technical data on the PS2-1800 controller are as follows [1]: power max. $1.8 \mathrm{~kW}$, input voltage $\max$. $200 \mathrm{~V}$, optimal MPP-voltage under Standard Test Conditions (STC) $V_{m p, S T C}>102 \mathrm{~V}$, motor current max. $14 \mathrm{~A}$, efficiency $\max .98 \%\left(\eta_{P S 2}=0.98\right)$, ambient temperature $-40-50{ }^{\circ} \mathrm{C}$, and enclosure class IP68.

The pump is centrifugal of the type SJ5-12, with a nonreturn valve, with efficiency of max. $65 \%$, made from stainless steel and run by a $1.7 \mathrm{~kW}$ direct current (DC) motor fed by one of the two generators [1]. The DC motor is brushless (BLDC motor) of the type ECDRIVE 1800-C, maintenance-free, water-filled, made from stainless steel and no electronics contained within itself. Other technical data on the ECDRIVE 1800-C motor are: efficiency max. $92 \%$, motor speed $900 \mathrm{rpm}-3300 \mathrm{rpm}$, insulation class $\mathrm{F}$, enclosure class IP68, and submersion max. $150 \mathrm{~m}$ [1]. According to [1], the depth of the pumping level $D_{p l}$ is $15 \mathrm{~m}$, the water pressure required for the operation of the drip-irrigation system is 2 bar (which is equivalent to a height of the discharge level $H_{d l}=20 \mathrm{~m}$ ), the total dynamic head is $H_{t d}=35 \mathrm{~m}$; there are no batteries or accumulators, and there is no water tank. In addition, the drip-irrigation system has an optimised operating point for a long lifespan and is operational at any global normal irradiance (gni) greater than $g n i_{\min }=150 \mathrm{~W} / \mathrm{m}^{2}$. According to [1], gni $i_{\min }=$ $150 \mathrm{~W} / \mathrm{m}^{2}$ represents the Sun switch light-sensor setting in the LORENTZ PumpScanner application.

Accordingly, it is assumed that there is a water tank of $100 \mathrm{~m}^{3}$. In this paper, it is also assumed that the total height difference between the pumping and discharge levels is $D_{p l}$ $+H_{d l}=31.5 \mathrm{~m}$, which is lower by $3.5 \mathrm{~m}$ (or $10 \%$ ) than the total dynamic head $H_{t d}$ of the considered PV water pumping 
system. Thus, losses due to friction in pipes and losses due to pressure drop through fittings and valves are modelled by a total head loss of $3.5 \mathrm{~m}$. This kind of equivalence is a very common practice, allowing a quick and safe assessment of the energy losses in pipes [17]. According to [1], water temperature and daily required amount of water are equal to $15{ }^{\circ} \mathrm{C}$ and $Q_{d}=40 \mathrm{~m}^{3} /$ day, respectively. The submersible pump system of the type PS2-1800 C-SJ5-12 was selected based on the peak hourly flow rate from the pump of $Q_{h, p}=$ $5 \mathrm{~m}^{3} / \mathrm{h}$ [1]. In addition to this, the maximum values for $H_{t d}$ and $Q_{h, p}$ are $70 \mathrm{~m}$ and $7.6 \mathrm{~m}^{3} / \mathrm{h}$, respectively. The manufacturer of the considered pump system is the company Bernt Lorentz GmbH \& Co. KG from Germany. The layout of the existing PV water pumping system, without the mentioned diesel-powered electric generator, is shown in Fig. 1.

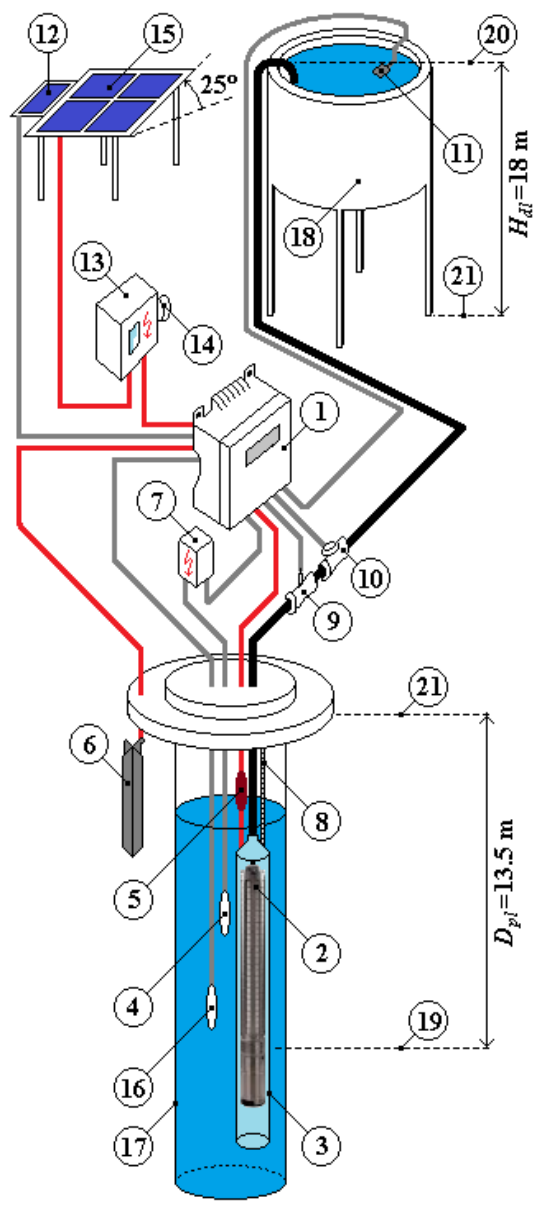

Fig. 1. Layout of the considered PV water pumping system for irrigation: (1) PS2-1800 controller; (2) Submersible pump system of the type PS21800 C-SJ5-12; (3) Stilling tube to protect the pump from dirt; (4) Well probe for dry run protection; (5) Cable splice kit from $2.5 \mathrm{~mm}^{2}$ to $6 \mathrm{~mm}^{2}$; (6) Grounding rod; (7) Surge protector for the water level sensor; (8) Safety rope; (9) Water meter; (10) Water pressure switch; (11) Float switch for water level detection in the water tank; (12) Sun switch light-sensor; (13) PV disconnect 440-40-3; (14) Lightning surge arrestor/protector; (15) PV generator; (16) Water level sensor; (17) Well with a minimum diameter of 0.102 m; (18) Water tank; (19) Pumping level; (20) Discharge level; (21) Ground surface level; $D_{p l}$ - the depth of the pumping level; and $H_{d l}$ - the height of the discharge level.

The submersible pump system is connected to the PS21800 controller by means of the cable splice kit and submersible drop cable. Details on the submersible drop cable are [1]: three copper conductors, cross-sectional area of one conductor $2.5 \mathrm{~mm}^{2}$, length $20 \mathrm{~m}$, and ethylenepropylene rubber (EPR) insulation. In addition, a single core EPR-cable with $2.5 \mathrm{~mm}^{2}$ copper conductor is used for grounding.

The PV generator consists of $18 \mathrm{PV}$ modules of the type Solo Line LX-160M. They are divided into three strings. The strings are connected in parallel, and in each of them, there are $6 \mathrm{PV}$ modules inclined at an angle of $25^{\circ}$. The manufacturer of the considered PV modules is the company Luxor Solar GmbH from Germany. The technical details of PV modules of the type Solo Line LX-160M under STC are outlined in Table I. According to [1], losses due to soiling on the upper surface of the considered PV module (i.e., dirt losses) amount to $5 \%$.

TABLE I. ELECTRICAL DATA, NOMINAL OPERATING CELL TEMPERATURE (NOCT), TEMPERATURE COEFFICIENTS, AND TECHNICAL SPECIFICATIONS OF THE PV MODULE SOLO LINE LX-160M UNDER STC [18].

\begin{tabular}{|c|c|}
\hline Electrical data under STC & Value \\
\hline Rated MPP-power $P_{m p, S T C}(\mathrm{Wp})$ & 160 \\
\hline Rated MPP-voltage $U_{m p, S T C}(\mathrm{~V})$ & 19.14 \\
\hline Rated MPP-current $I_{m p, S T C}(\mathrm{~A})$ & 8.36 \\
\hline Open-circuit voltage $U_{o c, S T C}(\mathrm{~V})$ & 23.08 \\
\hline Short-circuit current $I_{s c, S T C}(\mathrm{~A})$ & 8.99 \\
\hline Other electrical data & Value \\
\hline Output power tolerance $\tau_{P}(\%)$ & $0 /+5$ \\
\hline Maximum system voltage $V_{\max }(\mathrm{V})$ & 1000 \\
\hline NOCT and temperature coefficients & Value \\
\hline $\operatorname{NOCT}\left({ }^{\circ} \mathrm{C}\right)$ & 46 \\
\hline $\begin{array}{c}\text { Temperature coefficient of } P_{m p} \text {-power } k_{P m p} \\
\left(\% /{ }^{\circ} \mathrm{C}\right)\end{array}$ & -0.49 \\
\hline $\begin{array}{l}\text { Temperature coefficient of } U_{o c} \text {-voltage } k_{U o c} \\
\left(\% /{ }^{\circ} \mathrm{C}\right)\end{array}$ & -0.35 \\
\hline Temperature coefficient of $I_{s c}$-current $k_{I s c}\left(\% /{ }^{\circ} \mathrm{C}\right)$ & 0.05 \\
\hline Technical specifications & Value or type \\
\hline PV cell size $A_{\text {cell }}$ & $0.156 \times 0.156 \mathrm{~m}^{2}$ \\
\hline Number of PV cells in series $N_{s}$ & $4 \times 9=36$ \\
\hline PV cell type & Mono-crystalline \\
\hline PV module weight & $11.5 \mathrm{~kg}$ \\
\hline Output cable length & $0.85 \mathrm{~m}$ \\
\hline Output wire cross-sectional area & $4 \mathrm{~mm}^{2}$ \\
\hline Diode & $2 \times 12 \mathrm{~A}$ \\
\hline Socket & IP 65 \\
\hline
\end{tabular}

A couple of photographs of the considered PV generator are presented in Fig. 2 and Fig. 3. Figures 2 and 3 show the front and back sides of the PV generator (that consists of 18 PV modules of the type Solo Line LX-160M), respectively.

According to Fig. 2, there is a total of 20 PV modules of the type Solo Line LX-160M. The two additional PV modules are a part of a small off-grid system with batteries running the automation equipment, four solenoid valves, LED-based lights, LED-based reflector lamp with integrated sensors, security alarm system (excluding a video surveillance system), and chargers for various devices. The security alarm system represents a significant consumer of the electricity. Installed automation equipment has the capability of complete remote control, while the pump has a hydraulic control system (maintaining all control valves in closed position, switching the pump off, etc.). 


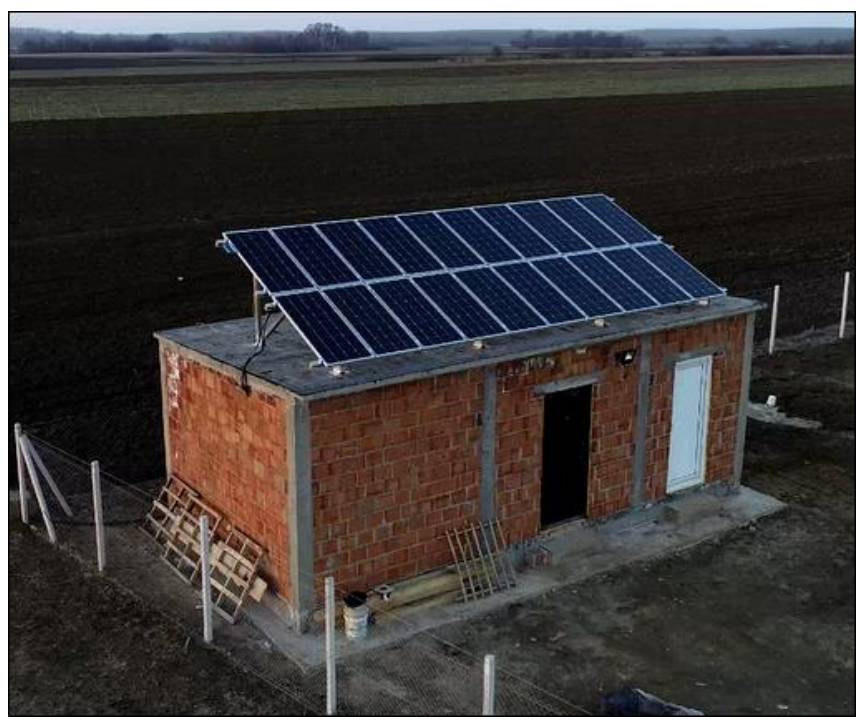

Fig. 2. Front side of the considered PV generator (the source of this photograph is https://tkpenergy.com/portfolio-items/pozarevac-solarnaelektrana-i-navodnjavnje-35ha-plantaza-tresanja/).

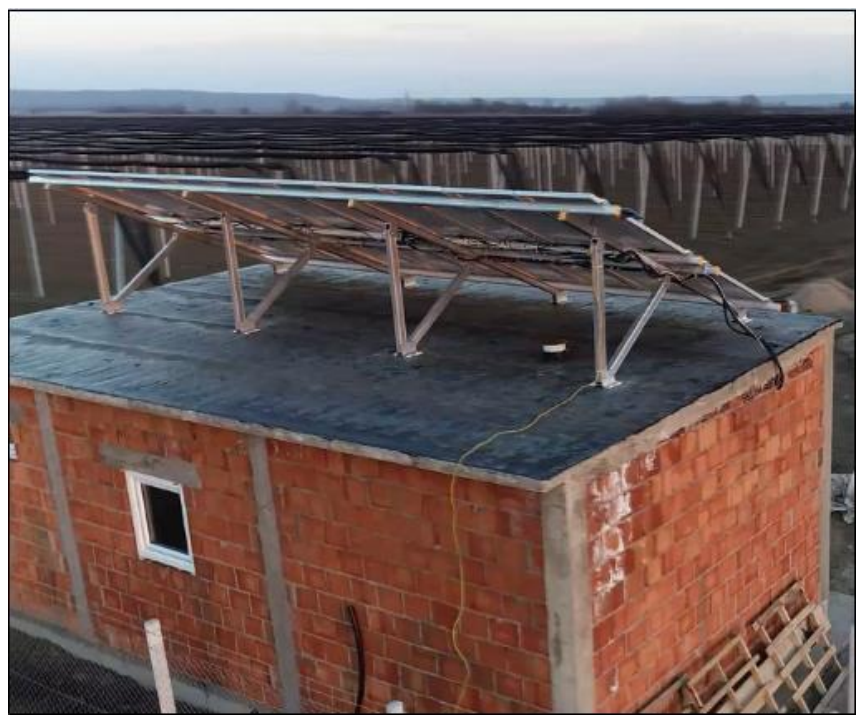

Fig. 3. Back side of the considered PV generator (the source of this photograph is https://tkpenergy.com/portfolio-items/pozarevac-solarnaelektrana-i-navodnjavnje-35ha-plantaza-tresanja/).

\section{B. Meteorological Variables}

For the needs of the proposed procedure, the following daily meteorological variables are used: sunshine duration $S$ in $\mathrm{h} /$ day, precipitation $\Delta_{R}$ in $\mathrm{mm} /$ day, and ambient air temperature $T_{a}$ in ${ }^{\circ} \mathrm{C}$. Monthly mean values of these daily variables are taken from the meteorological online service Weather Online UK and averaged over periods of 5, 10, 15, 20 , and 25 years, while the corresponding seasonal mean values are calculated based on them. The given periods are selected with respect to the end of 2020. The monthly and seasonal mean values for the variables $S, \Delta_{R}$, and $T_{a}$, together with the data collection period $t_{D C}$ and data availability $D_{A}$, are outlined in Table II.

\section{SIZING OF THE PV WATER PUMPING SYSTEM}

\section{A. Required Hydraulic Powers}

The required hydraulic power $P_{h}$ in $\mathrm{W}$ for any $\mathrm{PV}$ water pumping system can be calculated by the following equation

$$
P_{h}=\frac{\rho_{0} \times g \times Q_{d} \times H_{d t}}{3600 \times t_{\text {run }}},
$$

where $\rho_{0}=1000 \mathrm{~kg} / \mathrm{m}^{3}$ is the water density at temperature $4{ }^{\circ} \mathrm{C}, g=9.81 \mathrm{~m} / \mathrm{s}^{2}$ is the acceleration of gravity, $Q_{d}$ is the daily required amount of water in $\mathrm{m}^{3} / \mathrm{day}, H_{d t}$ is the total dynamic head in $\mathrm{m}$, and $t_{\text {run }}$ is the daily running time of the pump in h/day.

Assuming that the daily running time of the pump $t_{\text {run }}$ equals the sunshine duration $S$ that corresponds to the month with the lowest GNI value in the irrigation season, the peak hourly flow rate from the pump $Q_{h, p}$ in $\mathrm{m}^{3} / \mathrm{h}$ can be estimated as follows

$$
Q_{h, p}=\frac{Q_{d}}{S}
$$

where $S=t_{\text {run }}$ is the sunshine duration from Table II

\begin{tabular}{|c|c|c|c|c|c|c|c|c|c|c|c|c|c|c|c|}
\hline \multirow{3}{*}{$\begin{array}{c}t_{D C} \\
\text { (years) }\end{array}$} & \multirow{3}{*}{$\begin{array}{l}\text { Daily meteorological } \\
\text { variable }\end{array}$} & \multirow{3}{*}{$D_{A}(\%)$} & \multicolumn{12}{|c|}{ Monthly mean values } & \multirow{3}{*}{$\begin{array}{c}\text { Season. } \\
\text { mean } \\
\text { value }\end{array}$} \\
\hline & & & \multicolumn{4}{|c|}{ Months before } & \multicolumn{4}{|c|}{ Irrigation season } & \multicolumn{4}{|c|}{ Months after } & \\
\hline & & & Jan & Feb & Mar & Apr & May & Jun & Jul & Aug & Sep & Oct & Nov & Dec & \\
\hline \multirow{3}{*}{$\begin{array}{c}5 \\
(2016- \\
2020)\end{array}$} & $\begin{array}{c}\text { Sunshine duration } \\
\text { (h/day) }\end{array}$ & $38-60$ & 3.2 & 3.8 & 4.8 & 7.8 & 6.3 & 8.8 & 10.0 & 9.6 & 7.7 & 5.6 & 2.8 & 2.3 & 8.675 \\
\hline & Precipitation (mm/day) & $88-95$ & 1.2 & 1.5 & 1.7 & 1.5 & 2.7 & 3.9 & 1.2 & 1.5 & 1.0 & 1.6 & 1.4 & 1.2 & 2.3 \\
\hline & Air temperature $\left({ }^{\circ} \mathrm{C}\right)$ & $97-100$ & 1.7 & 6.6 & 9.8 & 15.2 & 18.1 & 23.1 & 24.2 & 25.2 & 20.6 & 15.1 & 9.6 & 4.5 & 22.65 \\
\hline \multirow{3}{*}{$\begin{array}{c}\mathbf{1 0} \\
(2011- \\
2020)\end{array}$} & $\begin{array}{c}\text { Sunshine duration } \\
\text { (h/day) }\end{array}$ & $59-80$ & 2.8 & 3.4 & 5.6 & 7.3 & 7.2 & 9.2 & 10.2 & 9.8 & 7.2 & 5.8 & 3.6 & 2.6 & 9.1 \\
\hline & Precipitation (mm/day) & $82-96$ & 1.3 & 1.4 & 1.9 & 1.4 & 3.3 & 2.6 & 2.0 & 1.2 & 1.7 & 1.5 & 1.2 & 1.2 & 2.3 \\
\hline & Air temperature $\left({ }^{\circ} \mathrm{C}\right)$ & $88-100$ & 2.8 & 5.3 & 9.6 & 14.7 & 18.1 & 22.7 & 24.6 & 25.1 & 20.5 & 14.9 & 9.7 & 4.3 & 22.625 \\
\hline \multirow{3}{*}{$\begin{array}{c}\mathbf{1 5} \\
(2006- \\
2020)\end{array}$} & $\begin{array}{c}\text { Sunshine duration } \\
\text { (h/day) }\end{array}$ & $69-86$ & 2.7 & 3.4 & 5.3 & 7.2 & 7.7 & 9.0 & 10.4 & 9.5 & 7.0 & 5.5 & 3.9 & 2.3 & 9.15 \\
\hline & Precipitation (mm/day) & $82-94$ & 1.3 & 1.7 & 2.0 & 1.4 & 2.9 & 2.9 & 3.7 & 3.4 & 1.5 & 1.6 & 1.3 & 1.3 & 3.2 \\
\hline & Air temperature $\left({ }^{\circ} \mathrm{C}\right)$ & 89-99 & 2.6 & 5.1 & 9.3 & 14.7 & 18.4 & 22.5 & 24.5 & 24.7 & 19.9 & 14.6 & 9.6 & 4.3 & 22.525 \\
\hline \multirow{3}{*}{$\begin{array}{c}\mathbf{2 0} \\
(2001- \\
2020)\end{array}$} & $\begin{array}{c}\text { Sunshine duration } \\
\text { (h/day) }\end{array}$ & $73-88$ & 2.6 & 3.5 & 5.3 & 6.8 & 7.8 & 9.0 & 9.9 & 9.2 & 6.8 & 5.5 & 3.7 & 2.2 & 8.975 \\
\hline & Precipitation (mm/day) & $84-93$ & 1.3 & 3.1 & 1.7 & 1.6 & 2.5 & 2.9 & 3.3 & 3.1 & 1.7 & 1.5 & 2.6 & 1.4 & 3.0 \\
\hline & Air temperature $\left({ }^{\circ} \mathrm{C}\right)$ & $89-97$ & 2.4 & 4.6 & 9.2 & 14.2 & 18.5 & 22.2 & 24.3 & 24.4 & 19.5 & 14.6 & 9.3 & 3.7 & 22.35 \\
\hline \multirow{3}{*}{$\begin{array}{c}\mathbf{2 5} \\
(1996- \\
2020)\end{array}$} & $\begin{array}{c}\text { Sunshine duration } \\
\text { (h/day) }\end{array}$ & $70-83$ & 2.6 & 3.7 & 5.3 & 6.8 & 7.8 & 9.1 & 9.8 & 9.1 & 6.8 & 5.5 & 3.6 & 2.3 & 8.95 \\
\hline & Precipitation (mm/day) & 79-90 & 1.3 & 2.8 & 1.5 & 1.5 & 2.2 & 2.7 & 3.1 & 2.9 & 1.7 & 1.5 & 2.3 & 1.5 & 2.7 \\
\hline & Air temperature $\left({ }^{\circ} \mathrm{C}\right)$ & $80-87$ & 2.4 & 4.7 & 9.2 & 14.3 & 18.5 & 22.2 & 24.1 & 24.2 & 19.4 & 14.4 & 9.3 & 3.8 & 22.25 \\
\hline
\end{tabular}
corresponding to the month of May (with $S=7.8 \mathrm{~h} /$ day). 
The previous assumption is based on the fact that, according to the World Meteorological Organization (WMO), the sunshine duration $S$ during a given period represents the sum of the time for which the direct normal irradiance $d n i$ exceeds $120 \mathrm{~W} / \mathrm{m}^{2}$ [19]. This means that the minimum value of the direct normal irradiation $D N I$ equals $120 \times S \mathrm{Wh} / \mathrm{m}^{2} /$ day, which is significantly lower than the value of $G N I=5.725 \mathrm{kWh} / \mathrm{m}^{2} /$ day corresponding to $\beta_{o m}=$ $25^{\circ}$ [1]. This approach replaces the previous one (which is based on the assumed pump efficiency) and represents the first novelty of the proposed procedure.

Inserting the values of $S$ from Table II in (2) results in the following peak hourly flow rates from the pump: $Q_{h, p 1}=$ $6.349 \mathrm{~m}^{3} / \mathrm{h}$ for $t_{D C}=5$ years, $Q_{h, p 2}=5.556 \mathrm{~m}^{3} / \mathrm{h}$ for $t_{D C}=10$ years, $Q_{h, p 3}=5.195 \mathrm{~m}^{3} / \mathrm{h}$ for $t_{D C}=15$ years, $Q_{h, p 4}=$ $5.128 \mathrm{~m}^{3} / \mathrm{h}$ for $t_{D C}=20$ years, and $Q_{h, p 5}=5.128 \mathrm{~m}^{3} / \mathrm{h}$ for $t_{D C}$ $=25$ years. Accordingly, it should be noted that, with the exception of the value for $Q_{h, p 5}$, the peak hourly flow rate from the pump decreases with increasing data collection period $t_{D C}$. The given exception is most likely caused by a higher value of the corresponding data availability. In addition, any difference between the values for $Q_{h, p}$ is lower than $1.221 \mathrm{~m}^{3} / \mathrm{h}$. It is therefore logical to continue the calculation only with the peak hourly flow rate $Q_{h, p}=Q_{h, p 5}$ that corresponds to the largest data collection period of $t_{D C}=$
25 years and the data availability of $D_{A}=70 \%-83 \%$. Furthermore, the flow rate $Q_{h, p}=5.128 \mathrm{~m}^{3} / \mathrm{h}$ is required for reading the value of the pump input power $P_{i n}$ in $\mathrm{kW}$ from the corresponding performance curve.

The performance diagram of the submersible pumping system PS2-1800 C-SJ5-12 is taken from [20] and represented in Fig. 4. Figure 4 illustrates the reading of the pump input power $P_{\text {in }}$ for the following two cases: (i) for the flow rate $Q_{h, p}=5.128 \mathrm{~m}^{3} / \mathrm{h}$ obtained using (2) and (ii) for the flow rate $Q_{h, p}=5 \mathrm{~m}^{3} / \mathrm{h}$ obtained using the LORENTZ COMPASS software [1]. The value $P_{i n}=1026 \mathrm{~W}$ was read in the case (i), while $P_{\text {in }}=985 \mathrm{~W}$ was read in the case (ii).

In addition, the following important details can be seen in Fig. 4: (i) operating point of the minimum pump input power and the zero hourly flow rate from the pump $\left(P_{i n, \min }\right.$, $\left.Q_{h, \min }\right)=\left(105 \mathrm{~W}, 0 \mathrm{~m}^{3} / \mathrm{h}\right)$, (ii) operating point of the maximum pump input power and the maximum hourly flow rate from the pump $\left(P_{i n, \max }, Q_{h, \max }\right)=\left(1495 \mathrm{~W}, 6.5 \mathrm{~m}^{3} / \mathrm{h}\right)$, and (iii) constraint $V_{m p, S T C}>102 \mathrm{~V}$ which defines the applicability of the given performance diagram. Accordingly, the pump operating points $\left(P_{i n, p}, Q_{h, p}\right)=$ $\left(1026 \mathrm{~W}, 5.128 \mathrm{~m}^{3} / \mathrm{h}\right)$ and $\left(P_{i n, p}^{\prime}, Q_{h, p}^{\prime}\right)=\left(985 \mathrm{~W}, 5 \mathrm{~m}^{3} / \mathrm{h}\right)$ belong to the range of normal operating conditions, and the required output voltage of PV generator should be greater than $102 \mathrm{~V}$.

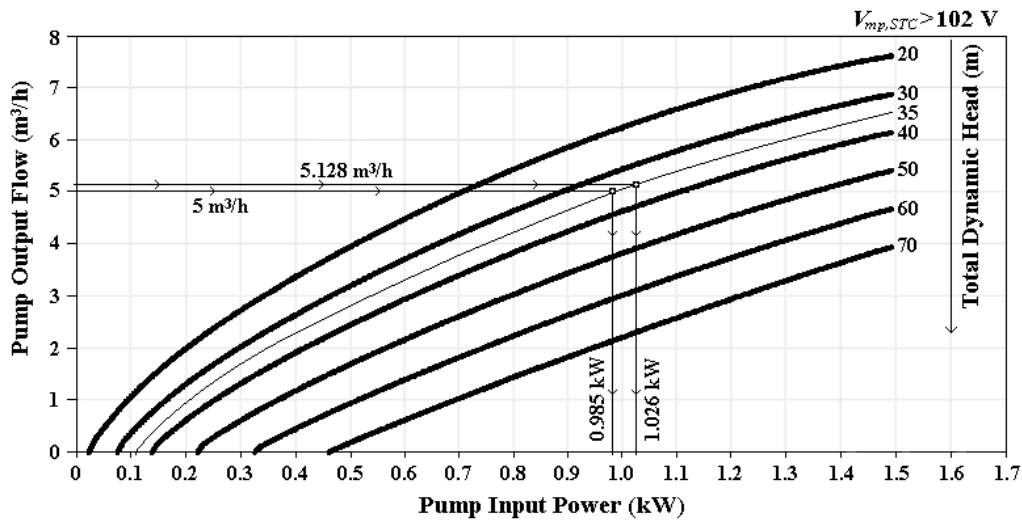

Fig. 4. Performance diagram of the submersible pumping system PS2-1800 C-SJ5-12 [20]: $V_{p m, S T C}$ - the MPP-voltage of PV generator under STC.

The electronic commutation methodology is used to control the supply voltage of the submersible pumping system PS2-1800 C-SJ5-12. Thus the pump operating points $\left(P_{i n, \min }, Q_{h, \min }\right), \quad\left(P_{i n, p}, Q_{h, p}\right)$ and $\left(P_{i n, \max }, Q_{h, \max }\right)$ may correspond to the voltages of electronically commutated motor $V_{E C}$ of $57 \mathrm{~V} \mathrm{EC}, 98 \mathrm{~V} \mathrm{EC}$ and $119 \mathrm{~V} \mathrm{EC}$, and motor currents $J_{E C}$ of $\left(P_{i n, \mathrm{~min}} / 57\right) \mathrm{A}, \quad\left(P_{i n, p} / 98\right) \mathrm{A}, \quad$ and $\left(P_{i n, \max } / 119\right) \mathrm{A}$, respectively. In the same manner, according to [1], the operating point $\left(P^{\prime}{ }_{i n, p}, Q_{h, p}^{\prime}\right)$ corresponds with $U_{E C}$ $=98 \mathrm{~V}$ EC and $J_{E C}=\left(P^{\prime}{ }_{i n, p} / 98\right)$ A. Therefore, based on the illustrated relationship between the pump output flow $Q_{h}$, total dynamic head $H_{d t}$, and pump input power $P_{\text {in }}$ from Fig. 4, the hydraulic power and efficiency of the pumping system that correspond to any operating point $\left(P_{i n}, Q_{h}\right)$ are

$$
P_{h}=\frac{\rho_{0} \times g \times Q_{h} \times H_{d t}}{3600}
$$

and

$$
\eta_{p s}=\frac{P_{h}}{P_{i n}},
$$

respectively, where $Q_{h}$ equals $Q_{h, \min }, Q_{h, p}$ or $Q_{h, \max }$, and $P_{\text {in }}$ equals $P_{i n, \min }, P_{i n, p}$ or $P_{i n, \max }$. Accordingly, the following values for $P_{h}$ and $\eta_{p s}$ are obtained: $P_{h}=0 \mathrm{~W}$ and $\eta_{p s}=0$ for $\left(P_{i n, \min }, Q_{h, \min }\right), P_{h}=489.1 \mathrm{~W}$ and $\eta_{p s}=0.4767$ for $\left(P_{i n, p}\right.$, $\left.Q_{h, p}\right)$, and $P_{h}=619.9 \mathrm{~W}$ and $\eta_{p s}=0.4147$ for $\left(P_{i n, \max }, Q_{h, \max }\right)$. For the purpose of comparison with the corresponding result from [1], the calculation of the values of $P_{h}$ and $\eta_{p s}$ for the operating point $\left(P_{i n, p}^{\prime}, Q_{h, p}^{\prime}\right)$ was also carried out. This calculation resulted in: $P_{h}=476.9 \mathrm{~W}$ and $\eta_{p s}=0.4841$ for $\left(P_{i n, p}^{\prime}, Q_{h, p}^{\prime}\right)$.

\section{B. Sizing of $P V$ Generator}

De-rated output power usually developed by a single PV module at a given location (Požarevac), during the irrigation season (May-August) under nominal operating cell temperature (NOCT) conditions or any other conditions, can 
be obtained from the following relationship [21], [22]

$$
P_{m p}=f_{\text {man }} \times f_{\text {dirt }} \times f_{\text {temp }} \times P_{m p, S T C} \times \frac{g n i}{g n i_{S T C}}
$$

in $\mathrm{Wp}$, where

$$
T_{c e l l}=T_{a}+(N O C T-20) \times \frac{g n i}{g n i_{N O C T}}
$$

is the operating PV cell temperature in ${ }^{\circ} \mathrm{C}, f_{\text {man }}$ is the derating factor for manufacturing tolerance (dimensionless), $f_{\text {dirt }}$ is the de-rating factor for dirt (dimensionless),

$$
f_{\text {temp }}=\left[1-\frac{k_{P m p}}{100} \times\left(25-T_{\text {cell }}\right)\right]
$$

is the de-rating factor for temperature (dimensionless), $P_{m p, S T C}$ is the rated MPP-power under STC in $\mathrm{Wp}, k_{P m p}$ is the temperature coefficient of MPP-power in $\% /{ }^{\circ} \mathrm{C}, T_{a}$ is the ambient air temperature in ${ }^{\circ} \mathrm{C}$ (Table II), NOCT is the nominal operating $\mathrm{PV}$ cell temperature in ${ }^{\circ} \mathrm{C}$, gni is the global normal irradiance in $\mathrm{W} / \mathrm{m}^{2}, g n i_{S T C}=1000 \mathrm{~W} / \mathrm{m}^{2}$ is the global normal irradiance at STC, and $g n i_{N O C T}=$ $800 \mathrm{~W} / \mathrm{m}^{2}$ is the global normal irradiance at NOCT conditions.

If mono-crystalline PV modules of the type Luxor Solo Line LX-160M are available, the same ones as in [1], then $P_{m p}=109.087 \mathrm{Wp}$ is obtained using (5) for the NOCT conditions $\left(g n i=g n i_{N O C T}, T_{a}=20^{\circ} \mathrm{C}\right.$, wind speed $v_{a}=$ $1 \mathrm{~m} / \mathrm{s}$, and $N O C T=46^{\circ} \mathrm{C}$ ). In this case, $f_{\text {man }}=1$ (because, according to the manufacturer's data from Table I, the output power tolerance is positive), $f_{\text {dirt }}=0.95$ (because all precipitations from Table II are lower than $5 \mathrm{~mm} /$ day), $P_{m p, S T C}=160 \mathrm{Wp}\left(\right.$ according to Table I), and $T_{\text {cell }}=$ NOCT . Furthermore, for STC $\left(g n i=g n i_{S T C}\right.$, air mass 1.5 solar spectral irradiance distribution, and $T_{\text {cell }}=25^{\circ} \mathrm{C}$ ), as well as for $f_{\text {man }}=1, f_{\text {dirt }}=1, N O C T=46^{\circ} \mathrm{C}$, and $T_{a}=-7.5^{\circ} \mathrm{C}$, (5) yields $P_{m p}=160 \mathrm{Wp}$.

The effect of dirt/soiling on the solar irradiation received by these PV modules is modelled with the de-rating factor for dirt $f_{\text {dirt }}$ in accordance with the findings correlating the PV cell efficiency with the precipitation $\Delta_{R}$ [23], [24]. Based on the data reported in [23]-[25], the factor $f_{\text {dirt }}$ is assumed to be equal to: (i) 0.95 for $\Delta_{R}<5 \mathrm{~mm} / \mathrm{day}$ - dirt losses of $5 \%$, (ii) 0.98 for $5 \mathrm{~mm} /$ day $\leq \Delta_{R}<20 \mathrm{~mm} /$ day - dirt losses of $2 \%$, and (iii) 1 for $\Delta_{R} \geq 20 \mathrm{~mm} /$ day - zero dirt losses. According to Table II, these conditions depend obviously on the data collection period $t_{D C}$ and the availability of data $D_{A}$ related to the precipitation $\Delta_{R}$. Based on Table II and knowledge of the phenomena of precipitation, no connection can be established between the data collection period $t_{D C}$ and the precipitation $\Delta_{R}$. However, the precipitation $\Delta_{R}$ is expected to be lower if less data are available and vice versa. The effects of the data collection period $t_{D C}$ and the availability of data $D_{A}$ related to the ambient air temperature $T_{a}$ on the PV cell temperature $T_{\text {cell }}$ have similar effects to those related to the precipitation $\Delta_{R}$.
The introduction of the conditions concerning the dirt losses in the design procedure of the PV water pumping systems represents the second novelty.

For the sizing of any PV generator under NOCT or any other operating conditions, the recalculated values of the short-circuit current of PV module

$$
I_{s c}=I_{s c, S T C} \times\left[1-\frac{k_{I s c}}{100} \times\left(25-T_{c e l l}\right)\right] \times \frac{g n i}{g n i_{S T C}}
$$

in $\mathrm{A}$ and the open-circuit voltage of PV module

$$
\begin{gathered}
U_{o c}=U_{o c, S T C} \times\left[1-\frac{k_{U o c}}{100} \times\left(25-T_{c e l l}\right)\right]+ \\
+k_{g n i} \times \ln \left(\frac{g n i}{g n i_{S T C}}\right)
\end{gathered}
$$

in $\mathrm{V}$ are also required [21], [26]-[28], where

$$
k_{\text {gni }}=\frac{N_{s} \times k \times\left(T_{\text {cell }}+273.157\right) \times n}{q_{e}}
$$

is the temperature coefficient of gni-irradiance in $\mathrm{V}, N_{s}=36$ is the number of $\mathrm{PV}$ cells connected in series, $k=$ $1.38064852 \times 10^{-23} \mathrm{~J} / \mathrm{K}$ is the Boltzmann constant, $T_{\text {cell }}$ is the operating PV cell temperature (at NOCT or any other conditions) in ${ }^{\circ} \mathrm{C}, n=1$ is the assumed ideality factor, and $q_{e}$ $=1.602 \times 10^{-19} \mathrm{C}$ is the elementary charge. The remaining parameters appearing in (8) and (9) are defined in Table I and after (6).

In addition, the MPP-current $I_{m p}$ in A and the MPPvoltage $U_{m p}$ in $\mathrm{V}$ of the considered type of $\mathrm{PV}$ modules should be recalculated for NOCT or any other conditions. According to [28], [29], the MPP-current can be obtained using a relationship similar to (8), i.e.,

$$
I_{m p}=I_{m p, S T C} \times\left[1-\frac{k_{I m p}}{100} \times\left(25-T_{c e l l}\right)\right] \times \frac{g n i}{g n i_{S T C}},
$$

where $I_{m p, S T C}$ is the MPP-current at STC in A (from Table I), and $k_{\text {Imp }}=-0.234 \% /{ }^{\circ} \mathrm{C}$ is the temperature coefficient of MPP-current. The value of the temperature coefficient $k_{\text {Imp }}$ is usually not provided by manufacturers, so it was estimated on the basis of known STC and NOCT conditions.

The remaining MPP-voltage can be obtained as the quotient from the MPP-power (5) and the MPP-current (11)

$$
U_{m p}=\frac{P_{m p}}{I_{m p}},
$$

where the MPP-power $P_{m p}$ and MPP-current $I_{m p}$ correspond to the same operating conditions.

According to the standard procedure [12], [15], the total number of required PV modules $N_{P V, t}$ is calculated by dividing the pump input power $P_{\text {in }}$ by the de-rated output power of one PV module $P_{m p}$ and by rounding the quotient so determined up to the nearest higher integer, i.e., 


$$
N_{P V, t}>\frac{P_{i n}}{P_{m p}},
$$

which gives $N_{P V, t}=9$ for $P_{i n}=985 \mathrm{~W}, N_{P V, t}=10$ for $P_{\text {in }}=$ $1026 \mathrm{~W}$, and $N_{P V, t}=14$ for $P_{i n}=1495 \mathrm{~W}$. Since all these values are different, it is important to introduce a unique criterion for determining the value of $N_{P V, t}$. This criterion should be based on the fact that the BLDC motor may be used at the rated power $\left(P_{m, r}=1700 \mathrm{~W}\right)$ for short periods during the irrigation season. In order to enable this operating regime, the input power $P_{i n}$ is assumed to be equal to the rated power $P_{m, r}$. Accordingly, the condition (13) becomes

$$
N_{P V, t}>\frac{P_{m, r}}{P_{m p}}=15.584,
$$

giving $N_{P V, t}=16$ for $P_{i n}=P_{m, r}=1700 \mathrm{~W}$.

Then, these $N_{P V, t}$ modules must be divided into $N_{s t r}$ strings based on the required minimum number of PV modules in one string $N_{P V, s}$. The required minimum number of $\mathrm{PV}$ modules in one string $N_{P V, s}$ can be found from the condition saying that, under STC, the optimal MPP-voltage of PV generator $V_{m p, S T C}=N_{P V, s} \times U_{m p, S T C}$ should be greater than the minimum MPP-voltage of PV generator $V_{m p, S T C, \min }=102 \mathrm{~V}$, which is usually shown in the pump performance diagram (Fig. 4). Accordingly, the required minimum number of PV modules in one string can be found from

$$
N_{P V, s}>\frac{V_{m p, S T C, \min }}{U_{m p, S T C}}=5.329 .
$$

In this case, the number $N_{P V, s}$, after rounding up to the nearest higher integer, amounts to 6 (i.e., $N_{P V, s}=6$ ).

The number of required strings $N_{s t r}$ can be obtained by rounding the quotient $N_{P V, t} / N_{P V, s}$ up. Accordingly, an application of the following condition

$$
N_{s t r}>\frac{N_{P V, t}}{N_{P V, s}}=2.667,
$$

after rounding the quotient $N_{P V, t} / N_{P V, s}$ up to the nearest higher integer, results in $N_{s t r}=3$. Since the number of PV modules in the third string cannot be set to a lower value than $N_{P V, s}=6$, the total number of required PV modules $N_{P V, t}$ should be increased accordingly, i.e.,

$$
N_{P V, t}=N_{s t r} \times N_{P V, s}=18 .
$$

The conditions concerning the total number of required PV modules $N_{P V, t}$, the required minimum number of PV modules in one string $N_{P V, s}$, and the number of required strings in one PV generator $N_{s t r}$, together with (17), can be regarded as the third novelty of this paper. Figure 5 shows wiring diagram and configuration of the PV generator designed.

In order to account for temperature, dirt, aging, contact resistance, and other losses of the PV generator, its size estimated by (13) should be increased by $20 \%$ in accordance with the standard procedure [30]. The manufacturer of the considered pumping system recommends at least $25 \%$ [31], while some researchers add $30 \%$ [32]. According to the proposed procedure, the losses due to temperature under NOCT conditions amount to -0.49 $\times(25-46)=10.29 \%$, the losses due to dirt under NOCT conditions amount to $5 \%$, and the total number of required PV modules $N_{P V, t}$ is increased by $12.5 \%$, which is in total $27.79 \%$. Therefore, it seems that the proposed procedure is in line with the most common used ones [1], [12], [15], [30]-[32].

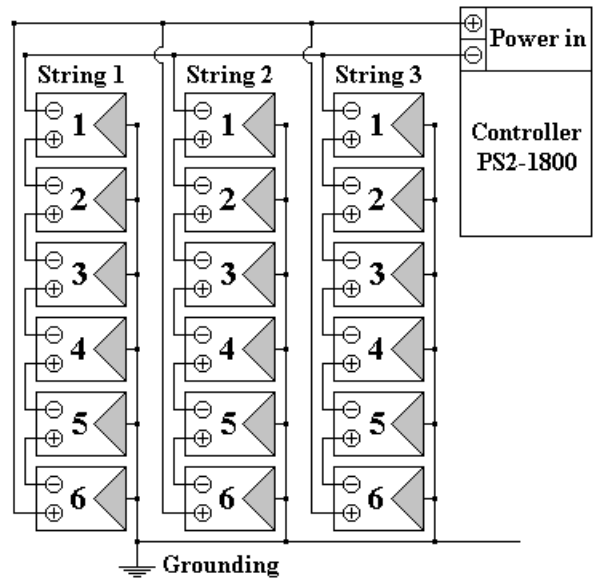

Fig. 5. Wiring diagram and configuration of the PV generator designed.

Finally, the PV generator performances under NOCT or any other operating conditions are the following:

$$
P_{m p}^{\prime}=N_{P V, t} \times P_{m p}
$$

- the de-rated MPP-power of PV generator in Wp,

$$
V_{m p}=N_{P V, s} \times U_{m p}
$$

- the MPP-voltage of PV generator in V,

$$
J_{m p}=N_{s t r} \times I_{m p}
$$

- the MPP-current of PV generator in A,

$$
V_{o c}=N_{P V, s} \times U_{o c}
$$

- the open-circuit voltage of PV generator in V, and

$$
J_{s c}=N_{s t r} \times I_{s c}
$$

- the short-circuit current of PV generator in A.

\section{Available Solar Energy}

In this subsection, the objective is to develop a model for the estimation of $G N I$ in $\mathrm{Wh} / \mathrm{m}^{2} /$ day (and $g n i$ in $\mathrm{W} / \mathrm{m}^{2}$ ) based on the sunshine duration $S$ in h/day and the elevation angle of the Sun $\alpha$ in degrees. For that purpose, the proposed model uses the definition of GNI based on unknown GTI, definition of GTI based on GHI estimated, and empirical model (correlation) originally developed by Sivkov for latitudes between $35^{\circ}$ and $65^{\circ}$ North [9]-[11]. The Sivkov model correlates GHI with the sunshine duration $S$ and the elevation angle of the $\operatorname{Sun} \alpha$. The 
elevation angle of the Sun (also known as the noon altitude of the Sun) is the angle at a point on Earth between the Sun and the horizon, which depends on the site latitude $\varphi$ in degrees and the declination angle of the Sun $\delta$ in degrees. Figure 6 illustrates the definition of GNI based on unknown $G T I$ and the definition of GTI based on GHI estimated.

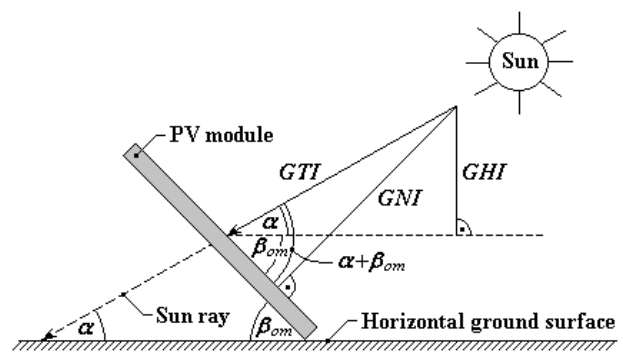

Fig. 6. Definition of GNI based on either unknown $G T I$ or $G H I$ estimated.

According to Fig. 6, GNI correlates with GTI in the following manner

$$
G N I=G T I \times \sin \left(\alpha+\beta_{o m}\right),
$$

while the correlation between $G T I$ and $G H I$ is

$$
G T I=\frac{G H I}{\sin \alpha} .
$$

In addition, $G H I$ is estimated by the mathematically converted form of the Sivkov model [9]-[11], rather than measured, i.e.,

$$
\begin{aligned}
G H I= & \frac{11.63}{N_{d t}} \times\left[4.9 \times\left(N_{d t} \times S\right)^{1.31}+\right. \\
& \left.+10500 \times(\sin \alpha)^{2.1}\right],
\end{aligned}
$$

where $N_{d t}$ represents the number of days in a given month. Table III outlines the values for $N_{d t}$.

Substituting (25) into (24), and then (24) so modified into (23), results in the model that correlates $G N I$ in $\mathrm{Wh} / \mathrm{m}^{2} /$ day with $S$ in h, i.e.,

$$
\begin{gathered}
G N I=\frac{\sin \left(\alpha+\beta_{o m}\right)}{N_{d t} \times \sin \alpha} \times\left[56.987 \times\left(N_{d t} \times S\right)^{1.31}+\right. \\
\left.+122115 \times(\sin \alpha)^{2.1}\right],
\end{gathered}
$$

where

$$
\alpha=90-\phi+\delta
$$

is the elevation angle of the Sun in degrees, $\varphi=44^{\circ} 366^{\prime} 50^{\prime \prime}=$ $44.614^{\circ}$ is the latitude of Požarevac,

$$
\delta=23.45 \times \sin \left(360 \times \frac{284+N_{m d}}{365}\right)
$$

is the declination angle of the Sun in degrees, and $N_{m d}$ is the ordinal number of the $15^{\text {th }}$ day of a given month within a calendar year. Table III gives the values for $N_{m d}$.

TABLE III. THE NUMBER OF DAYS IN EACH MONTH AND THE ORDINAL NUMBER OF THE $15^{\text {TH }}$ DAY OF EACH MONTH WITHIN A CALENDAR YEAR.

\begin{tabular}{|c|c|c|c|c|c|c|c|c|c|c|c|c|}
\hline Month & Jan & Feb & Mar & Apr & May & Jun & Jul & Aug & Sep & Oct & Nov & Dec \\
\hline$N_{d t}$ & 31 & 28 & 31 & 30 & 31 & 30 & 31 & 31 & 30 & 31 & 30 & 31 \\
\hline$N_{m d}$ & 15 & 46 & 74 & 105 & 135 & 166 & 196 & 227 & 258 & 288 & 319 & 349 \\
\hline
\end{tabular}

The approximate model (26) represents the fourth novelty of this paper. The potential introduction of a de-rating factor for an expected overestimation of the GNI value due to the application of the Sivkov empirical model will be considered in Section IV. According to [10], [11], the value of this de-rating factor should be between 0.9 and 0.956 .

\section{Output Electrical Parameters of PV Generator}

Losses in the submersible drop EPR-cable $\Delta P_{c}$ in $\mathrm{W}$ necessary for the determination of output electrical parameters of the PV generator (under NOCT or any other operating conditions) are estimated using the following formula

$$
\begin{aligned}
\Delta P_{c}=N_{c} \times \frac{L_{c}}{A_{c}} \times \rho_{c, 20} & \times\left[1+\alpha_{c, 20} \times\left(T_{c, c p}-20\right)\right] \times \\
& \times \frac{P_{i n}^{2}}{V_{E C}^{2}},
\end{aligned}
$$

where $N_{c}=2$ is the number of simultaneously energised conductors (in ECDRIVE 1800-C motor during bipolar operation, at any time across DC bus, two stator windings come in series [33]), $L_{c}$ is the cable length in $\mathrm{m}, A_{c}$ is the cross-sectional area of one conductor in $\mathrm{mm}^{2}, \rho_{c, 20}=$
$0.017241 \Omega \cdot \mathrm{mm}^{2} / \mathrm{m}$ is the resistivity of a copper conductor at $20{ }^{\circ} \mathrm{C}, \alpha_{c, 20}=0.003931 /{ }^{\circ} \mathrm{C}$ is the temperature coefficient of resistivity of a copper conductor at $20^{\circ} \mathrm{C}, T_{c, c p}=90{ }^{\circ} \mathrm{C}$ is the continuously permissible temperature of EPR-cables, $P_{\text {in }}$ is the pump input power in $\mathrm{W}$, and $V_{E C}$ is the voltage of electronically commutated motor in V EC.

The total output power from the PV generator $P_{P V \text {,out }}$ in W (under NOCT or any other operating conditions) can be obtained as the sum of the pump input power $P_{i n}$, the losses in the submersible drop cable $\Delta P_{c}$, and the losses in the PS21800 controller $\Delta P_{P S 2}$, i.e.,

$$
P_{P V, \text { out }}=P_{\text {in }}+\Delta P_{c}+\Delta P_{P S 2},
$$

where the losses $\triangle P_{P S 2}$ are assumed to be equal to the minimum possible value of $0.02 \times P_{P V \text {, out }}$ (according to the maximum efficiency of the PS2-1800 controller $\eta_{P S 2}=$ 0.98). Accordingly, the efficiency of the submersible drop cable is

$$
\eta_{c}=\frac{P_{i n}}{P_{i n}+\Delta P_{c}}
$$

The losses in the submersible drop cable and PS2-1800 
controller are usually expressed as a percentage of the total output power of the PV generator in the following manner:

$$
\Delta P_{c, p}=\frac{\Delta P_{c}}{P_{P V, \text { out }}} \times 100
$$

in $\%$, and

$$
\Delta P_{P S 2, p}=\frac{\Delta P_{P S 2}}{P_{P V, \text { out }}} \times 100
$$

in $\%$, respectively.

If the total output power from the PV generator $P_{P V \text {,out }}$ is known, then corresponding output voltage $V_{P V, \text { out }}$ in $\mathrm{V}$ and output current $J_{P V, \text { out }}$ in A can be estimated by means of the following equations [34]:

$$
V_{P V, \text { out }}=\left(V_{o c}-V_{m p}\right) \times\left(1-\frac{P_{P V, \text { out }}}{V_{m p} \times J_{m p}}\right)^{1 / C}+V_{m p}
$$

and

$$
J_{P V, \text { out }}=\frac{V_{m p} \times J_{m p}}{V_{P V, \text { out }}} \times\left[1-\left(\frac{V_{P V, \text { out }}-V_{m p}}{V_{o c}-V_{m p}}\right)^{C}\right],
$$

respectively, where $C=3.07$ for the PV generator that consists of the PV modules of the type Luxor Solo Line LX160M type. The value of exponent $C$ depends on the type of installed PV modules and is determined based on a single known operating point of the PV generator [34]. According to [34], (34) and (35) are valid for $V_{m p} \leq V_{P V, \text { out }} \leq V_{o c}$ and $C$ $>1$. The above calculation method of the output electrical parameters of PV generator replaces other existing methods and represents the fifth novelty introduced.

\section{E. Electricity Generation from PV Generator}

The efficiency of the PV generator $\eta_{P V, r}$ at reference STC conditions can be calculated based on gni $_{S T C}$ as in [30], i.e.,

$$
\eta_{P V, r}=\frac{V_{m p} \times J_{m p}}{A_{P V} \times g n i_{S T C}},
$$

where $A_{P V}=N_{P V, t} \times N_{s} \times A_{\text {cell }}=18 \times 36 \times 0.156^{2}=$ $15.769728 \mathrm{~m}^{2}$ is the effective area of the PV generator. Based on this, the efficiency of the PV generator $\eta_{P V}$ at NOCT or any other operating conditions is

$$
\eta_{P V}=f_{m} \times \eta_{P V, r} \times\left[1-\beta_{r} \times\left(T_{\text {cell }}-25\right)\right],
$$

where

$$
f_{m}=f_{\text {man }} \times f_{\text {dirt }} \times f_{\text {temp }}
$$

is the coupling factor that describes the fraction of the rated MPP-power transferred from the PV generator to the subsystem consisted of submersible pumping system, motor drop cable, and PS2 controller, $T_{\text {cell }}$ is the PV cell temperature estimated using (6) for $g n i=G N I / t_{\text {run }}$,

$$
\beta_{r}=\frac{1}{T_{0}-25}=\frac{1}{245} 1 /{ }^{\circ} \mathrm{C}
$$

is the appropriate temperature coefficient that depends on $\mathrm{PV}$ cell material and operating conditions, and $T_{0}=270^{\circ} \mathrm{C}$ is the temperature at which the electrical efficiency of a mono- or polycrystalline PV module drops to zero [17], [35].

The monthly mean values of daily electricity generation from the PV generator $E_{P V}$ in Wh/day can be calculated from [30]

$$
E_{P V}=\eta_{P V} \times A_{P V} \times G N I,
$$

where the monthly mean value of daily $G N I$ in $\mathrm{Wh} / \mathrm{m}^{2} /$ day is estimated using (26).

\section{F. Checking System Design to Daily Water Requirement}

The required daily hydraulic energy $E_{h}$ in Wh/day is calculated using the following equation [30]

$$
E_{h}=P_{h} \times t_{\text {run }}=\eta_{s s} \times E_{P V}=\eta_{p s} \times \eta_{c} \times \eta_{P S 2} \times E_{P V},
$$

where $P_{h}$ is the required hydraulic power (3) corresponding to the pump output flow $Q_{h}$ in $\mathrm{m}^{3} / \mathrm{h}, t_{\text {run }}=S$ is the daily running time of the pump in h/day, and $\eta_{s s}=\eta_{p s} \times \eta_{c} \times \eta_{P S 2}$ is the efficiency of the subsystem consisted of the submersible pumping system, motor drop cable, and PS2 controller.

Based on (4), (40), and (41), the pump input power $P_{\text {in }}$ in $\mathrm{kW}$ can be expressed as

$$
P_{i n}=\eta_{c} \times \eta_{P S 2} \times \eta_{P V} \times A_{P V} \times \frac{g n i}{1000},
$$

where $g n i=G N I / t_{\text {run }}$ represents the monthly mean value of daily gni in $\mathrm{W} / \mathrm{m}^{2}$.

The final check on the design is to see whether the electricity supplied by the PV generator (40) to the submersible pumping system can enable the pump to supply the daily required amount of water $Q_{d}=40 \mathrm{~m}^{3} /$ day. This can be carried out by referring the pump performance diagram from Fig. 4. As shown in Fig. 4, the required pump input power $P_{i n}$ in $\mathrm{kW}$ was found by locating the operating point $\left(P_{i n}, Q_{h}\right)$ on the pump performance curve where the pump output flow $Q_{h}$ in $\mathrm{m}^{3} / \mathrm{h}$ meets the total dynamic head $H_{d t}$ in $\mathrm{m}$, and then reading the required value of $P_{\text {in }}$ in $\mathrm{kW}$ at that point. Working backwards, a pump output flow $Q_{h}$ in $\mathrm{m}^{3} / \mathrm{h}$ can be estimated based on the pump input power $P_{\text {in }}$ in $\mathrm{kW}$ obtained using (42) for any hour of a given day. In order to carry this out, the daily global normal irradiance gni and the total dynamic head $H_{d t}$ are assumed to be constant during the time $t_{\text {run }}$. Thus the monthly mean value of daily water production $Q_{d}^{\prime}$ in $\mathrm{m}^{3} /$ day can be obtained using

$$
Q_{d}^{\prime}=Q_{h} \times t_{\text {run }}
$$




$$
Q^{\prime}{ }_{d}=Q_{h} \times \frac{t_{\text {run }}+t_{\text {peak }}}{2},
$$

where the value for $Q_{h}$ is read out from the corresponding performance curve of the pump, and $t_{\text {peak }}=$ GNI/gnisTC stands for the peak sun hours. If $Q^{\prime}{ }_{d}$ is significantly greater or lower than $Q_{d}=40 \mathrm{~m}^{3} / \mathrm{day}$, then the PV generator should be redesigned. According to the standard IEC 62253 [12], the daily water production $Q^{\prime}{ }_{d}$ should be within a tolerance of $-5 \%$ to $+20 \%$ of the daily required amount of water $Q_{d}=$ $40 \mathrm{~m}^{3} /$ day. If $Q_{d}^{\prime}$ is outside the tolerance, then a redesign is required by means of a different effective area of the PV generator, a different number of PV modules or a different configuration of the PV generator. Moreover, (44) is included and considered because it represents a more realistic estimation in comparison to (43).

The use of the monthly mean value of daily global normal irradiance $g n i=G N I / t_{\text {run }}$ instead of a number of monthly mean values of hourly global normal irradiances [1], [12], [15], [16] or the peak global normal irradiance $g n i_{S T C}=$ $G N I / t_{\text {peak }}=1000 \mathrm{~W} / \mathrm{m}^{2}$ represents the sixth novelty of the proposed procedure. The use of the daily $g n i=G N I / t_{\text {run }}$ corresponds with the use of (42) for a single "average" hour of a given day, while the use of the hourly gni corresponds with the use of (42) for each hour of a given day [1], [15], [16].

\section{RESUlTS AND DISCUSSION}

The results obtained by applying the software LORENTZ COMPASS and proposed procedure are outlined in Table IV. This table of results enables a comparative presentation of the parameters of the PV generator, PS2-1800 controller, motor drop cable, and submersible pumping system PS2$1800 \mathrm{C}-\mathrm{SJ} 5-12$. The parameters are generated for the following four cases: (i) $Q_{h, \text { min }}=0 \mathrm{~m}^{3} / \mathrm{h}$ and NOCT conditions, (ii) $Q_{\mathrm{h}, p}^{\prime}=5 \mathrm{~m}^{3} / \mathrm{h}$ and NOCT conditions, (iii) $Q_{h, p}=5.128 \mathrm{~m}^{3} / \mathrm{h}$ and NOCT conditions, and (iv) $Q_{h, \max }=$ $6.5 \mathrm{~m}^{3} / \mathrm{h}$ and STC. The results related to the cases (i), (ii), and (iv) are obtained by means of both procedures, while those related to the case (iii) are obtained only by means of the proposed procedure. The results generated by the software LORENTZ COMPASS are originally taken from the reference [1].

TABLE IV. A COMPARATIVE PRESENTATION OF THE RESULTS OBTAINED BY APPLYING THE SOFTWARE LORENTZ COMPASS (COMPASS) AND PROPOSED PROCEDURE (PP).

\begin{tabular}{|c|c|c|c|c|c|c|c|c|c|}
\hline \multirow{2}{*}{$\begin{array}{l}\text { Component of } \\
\text { PV water } \\
\text { pumping system }\end{array}$} & \multicolumn{2}{|c|}{ Parameter } & \multicolumn{2}{|c|}{$Q_{h, \min }+$ NOCT } & \multicolumn{2}{|c|}{$Q_{h, p}^{\prime}+$ NOCT } & \multirow{2}{*}{$\frac{Q_{h, p}+\text { NOCT }}{\text { PP }}$} & \multicolumn{2}{|c|}{$Q_{h, \max }+\mathrm{STC}$} \\
\hline & Symbol & Unit & COMPASS & $\mathbf{P P}$ & COMPASS & $\mathbf{P P}$ & & COMPASS & $\mathbf{P P}$ \\
\hline \multirow{12}{*}{ PV generator } & $T_{\text {cell }}$ & ${ }^{\circ} \mathrm{C}$ & - & - & 46 & 46 & 46 & 25 & 25 \\
\hline & $f_{\text {temp }}$ & - & - & - & 0.9 & 0.897 & 0.897 & 1 & 1 \\
\hline & $f_{\text {dirt }}$ & - & - & - & 0.95 & 0.95 & 0.95 & 1 & 1 \\
\hline & $f_{\operatorname{man}}$ & - & - & - & 1 & 1 & 1 & 1 & 1 \\
\hline & $P_{m p}^{\prime}$ & $\mathrm{Wp}$ & - & - & 1965 & 1963.6 & 1963.6 & 2880 & 2880 \\
\hline & $V_{m p}$ & $\mathrm{~V}$ & - & - & 103 & 102.93 & 102.93 & 115 & 114.84 \\
\hline & $J_{m p}$ & $\mathrm{~A}$ & - & - & 19 & 19.08 & 19.08 & 25 & 25.08 \\
\hline & $V_{o c}$ & $\mathrm{~V}$ & - & - & 126 & 126.98 & 126.98 & 139 & 138.48 \\
\hline & $J_{s c}$ & $\mathrm{~A}$ & - & - & 21 & 21.35 & 21.35 & 27 & 26.97 \\
\hline & $P_{P V, \text { out }}$ & $\mathrm{W}$ & - & - & 1035 & 1041.4 & 1086.3 & - & 1582.2 \\
\hline & $V_{P V, \text { out }}$ & $\mathrm{V}$ & - & - & 121 & 121.73 & 121.43 & - & 133.08 \\
\hline & $J_{P V, \text { out }}$ & $\mathrm{A}$ & - & - & 8.9 & 8.55 & 8.94 & - & 11.89 \\
\hline $\begin{array}{l}\text { PS2-1800 } \\
\text { controller }\end{array}$ & $\Delta P_{P S 2, p}$ & $\%$ & - & 2 & - & 2 & 2 & - & 2 \\
\hline \multirow{2}{*}{$\begin{array}{c}\text { Motor drop } \\
\text { cable }\end{array}$} & $\Delta P_{c}$ & $\mathrm{~W}$ & - & 1.19 & - & 35.53 & 38.55 & - & 55.52 \\
\hline & $\Delta P_{c, p}$ & $\%$ & 1.1 & 1.1 & 3.5 & 3.41 & 3.55 & - & 3.51 \\
\hline \multirow{5}{*}{$\begin{array}{c}\text { Submersible } \\
\text { pumping system } \\
\text { PS2-1800 } \\
\text { C-SJ5-12 }\end{array}$} & $P_{i n}$ & $\mathrm{~W}$ & 105 & 105 & 985 & 985 & 1026 & - & 1495 \\
\hline & $V_{E C}$ & V EC & 5.7 & 57 & 98 & 98 & 98 & - & 119 \\
\hline & $J_{E C}$ & A & 1.8 & 1.84 & 10 & 10.05 & 10.47 & - & 12.56 \\
\hline & $Q_{h}$ & $\mathrm{~m}^{3} / \mathrm{h}$ & 0 & 0 & 5 & 5 & 5.128 & - & 6.5 \\
\hline & $\eta_{p s}$ & $\%$ & 0 & 0 & 46 & 48.41 & 47.67 & - & 41.47 \\
\hline
\end{tabular}

As can be seen from Table IV, the results obtained by means of the proposed procedure agree to a very high extent with those obtained by means of the software LORENTZ COMPASS. It is therefore important to note here that the differences between the results obtained for the case (ii) and the results obtained for the case (iii) are negligible. The results from Table IV correspond to the data collection period of $t_{D C}=25$ years and the data availability of $D_{A}=$ $70 \%-83 \%$. Results corresponding to the data collection period of $t_{D C}=10$ years and the data availability of $D_{A}=$ $88 \%-100 \%$ were also calculated. These results are not presented in Table IV. According to Table IV and the results corresponding to $t_{D C}=10$ years and $D_{A}=88 \%-$
$100 \%$, it is found that there are no effects of $t_{D C}$ and $D_{A}$ on the parameters of the main components of the PV water pumping system.

The monthly mean values of daily ambient air temperature $T_{a}$ in ${ }^{\circ} \mathrm{C}$ are given in Fig. 7. The monthly mean values of daily $T_{a}$ taken from the NASA Langley Research Centre [1] and the Weather Online UK service are labelled with (a) and (b), respectively. In the last column labelled with "Av.", the ambient air temperatures $T_{a}=11^{\circ} \mathrm{C}$ and $T_{a}$ $=22.3{ }^{\circ} \mathrm{C}$ are obtained by averaging the corresponding monthly mean values over the entire year and over the irrigation season (May-August), respectively. The seasonal mean value of daily $T_{a}$ corresponding to the monthly mean 
values of daily $T_{a}$ from the NASA Langley Research Centre equals $20^{\circ} \mathrm{C}$.

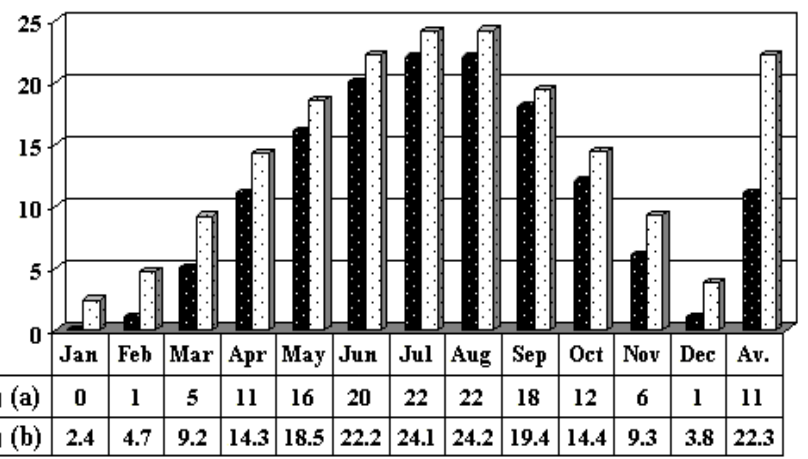

Fig. 7. The monthly mean values of daily ambient air temperature $T_{a}$ in ${ }^{\circ} \mathrm{C}$ : (a) The values taken from the NASA Langley Research Centre and then averaged over the entire year [1]; (b) The values taken from the Weather Online UK service and then averaged over the irrigation season.

According to Fig. 7, the effects of the data collection period $t_{D C}$ and the data availability $D_{A}$ on the ambient air temperature $T_{a}$ are obvious. However, the values for $t_{D C}$ and $D_{A}$ were not provided in [1]. In addition, the monthly mean values of daily $T_{a}$ for February and March are affected to a considerable extent. Moreover, all the monthly mean values of daily $T_{a}$ taken from the NASA Langley Research Centre are lower than those taken from the Weather Online UK.

The monthly mean values of daily precipitation $\Delta_{R}$ in $\mathrm{mm} / \mathrm{day}$ are given in Fig. 8. The values of $\Delta_{R}$ taken from the NASA Langley Research Centre [1] and the Weather Online UK are indicated with (a) and (b), respectively. The precipitations $\Delta_{R}=1.8 \mathrm{~mm} /$ day and $\Delta_{R}=2.7 \mathrm{~mm} /$ day appearing in the column labelled with "Av." represent the corresponding annual and seasonal mean values of daily $\Delta_{R}$, respectively. The seasonal mean value of daily $\Delta_{R}$, obtained using the monthly mean values of daily $\Delta_{R}$ from the NASA Langley Research Centre, amounts to $2.3 \mathrm{~mm} / \mathrm{day}$.

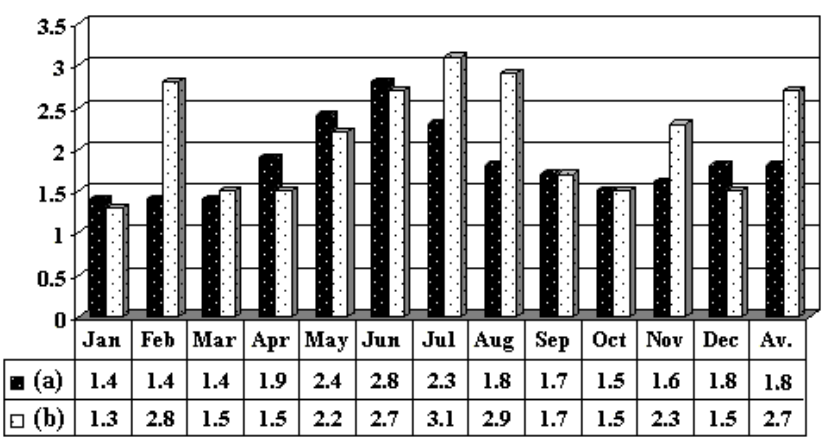

Fig. 8. The monthly mean values of daily precipitation $\Delta_{R}$ in $\mathrm{mm} /$ day: (a) The values taken from the NASA Langley Research Centre and then averaged over the entire year [1]; (b) The values taken from the Weather Online UK service and then averaged over the irrigation season.

Based on Fig. 8, it is evident that the data collection period $t_{D C}$ and the data availability $D_{A}$ may affect the precipitation $\Delta_{R}$. Since the values of $t_{D C}$ and $D_{A}$ from the NASA Langley Research Centre were not available, the discussion about the effects of these parameters has been reduced accordingly. In addition, all the values of precipitation $\Delta_{R}$ are lower than $5 \mathrm{~mm} /$ day that could not affect in any manner the final design of the considered PV water pumping system. In this case, the effect of $t_{D C}$ or $D_{A}$ on the monthly mean value of daily $\Delta_{R}$ should be the greatest for February.

Figure 9 illustrates and quantifies the monthly and seasonal mean values of daily global normal irradiation on a south-oriented surface inclined at $25^{\circ} \mathrm{GNI}$ in $\mathrm{kWh} / \mathrm{m}^{2} /$ day. The column labelled with the acronym "Av." contains the seasonal mean values of daily GNI. The monthly and seasonal mean values of daily $G N I$ indicated with (a) are generated using the software LORENTZ COMPASS [1], while those indicated with (b) are generated using the proposed procedure, i.e., (26).

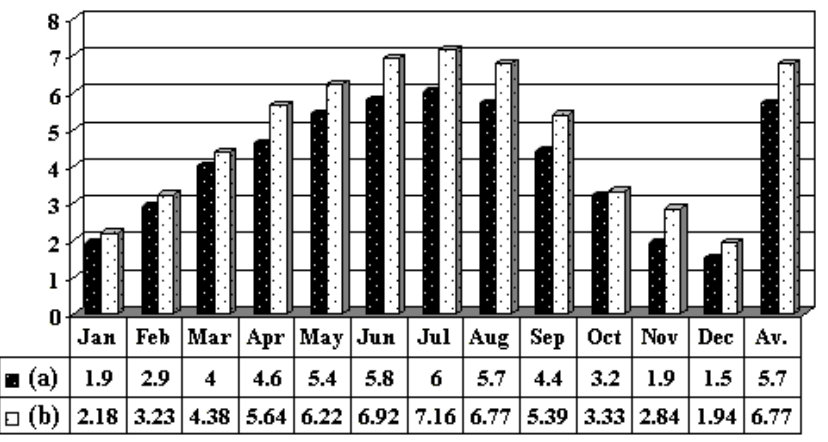

Fig. 9. The monthly and seasonal mean values of daily global normal irradiation on a south-oriented surface inclined at $25^{\circ} \mathrm{GNI}$ in $\mathrm{kWh} / \mathrm{m}^{2} /$ day: (a) The values taken from [1]; (b) The values calculated using (26) and then averaged over the irrigation season.

According to Fig. 9, the monthly mean values of daily GNI obtained using the proposed procedure are in average about $20 \%$ above the corresponding values obtained using the software LORENTZ COMPASS. The values generated by the proposed procedure and LORENTZ COMPASS [1] are also in line with other existing data on available solar energy in Serbia. For instance, the differences between the monthly mean values of daily GNI presented in this paper, on one side, and the ones in [16], on the other, are comparable with the differences shown in Fig. 9. Accordingly, the overestimation made by the application of (26) lies within the acceptable limits of solar irradiation and the introduction of any de-rating factor for solar irradiation can be regarded as unnecessary.

Figure 10 shows the monthly and seasonal mean values of daily electricity generation from the $\mathrm{PV}$ generator $E_{P V}$ in $\mathrm{kWh} / \mathrm{day}$. The last column indicated with "Av." contains the corresponding seasonal mean values of daily $E_{P V}$. The first row of data in Fig. 10, indicated with (a), contains the monthly mean values of daily $E_{P V}$ which are generated using the software LORENTZ COMPASS [1]. The second row indicated with (b) provides the data calculated using (40).

As can be seen from Fig. 10, the difference between the monthly mean values of daily $E_{P V}$ taken from [1] and those calculated using (40) ranges between $-3.79 \%$ for October and $+28.9 \%$ for November. In general, these differences follow the differences between the monthly mean values of daily GNI taken from [1] and those calculated using (26), which are illustrated and quantified in Fig. 9. This is another confirmation of the applicability of the Sivkov empirical model in the design procedure of the off-grid PV water pumping systems for irrigation. 


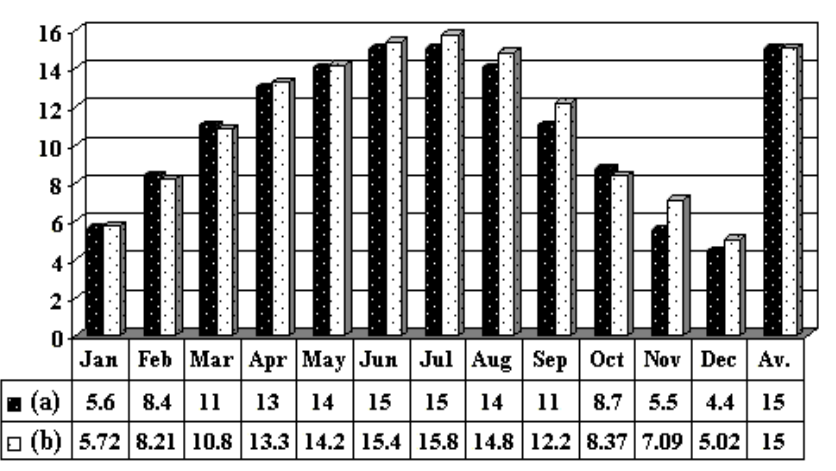

Fig. 10. The monthly and seasonal mean values of daily electricity generation from the PV generator $E_{P V}$ in $\mathrm{kWh} /$ day: (a) The values taken from [1]; (b) The values calculated using (40) and then averaged over the irrigation season.

Figure 11 presents the monthly and seasonal mean values of daily water production $Q_{d}^{\prime}$ in $\mathrm{m}^{3} /$ day. The values taken from [1], the ones calculated using (43), and the ones calculated using (44) are indicated with (a), (b), and (c), respectively. The column labelled with "Av." contains the corresponding seasonal mean values of daily water production $Q^{\prime}$.

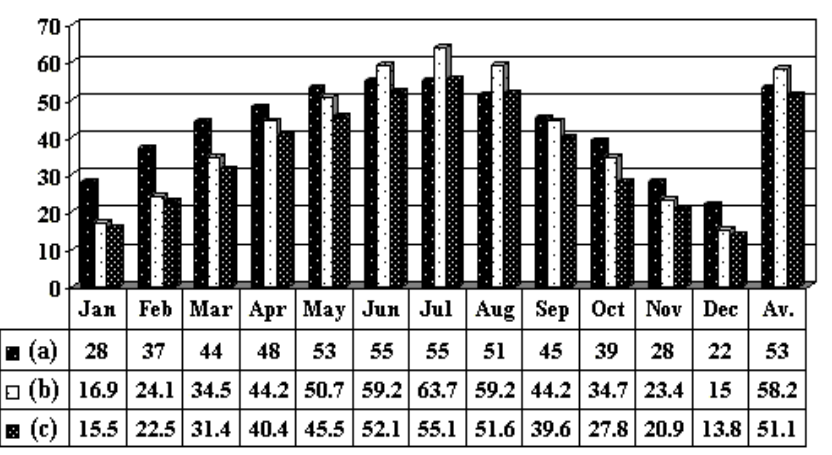

Fig. 11. The monthly and seasonal mean values of daily water production $Q_{d}^{\prime}$ in $\mathrm{m}^{3} /$ day: (a) The values taken from [1]; (b) The values calculated using (43) and then averaged over the irrigation season; (c) The values calculated using (44) and then averaged over the irrigation season.

Based on Fig. 11 and the standard IEC 62253 [12], for the month of May having the lowest GNI value in the irrigation season, the daily water productions in the cases (a) and (b) are $12.5 \%$ and $6.75 \%$ above the upper tolerance limit, respectively. In the case (c), the daily water production $Q_{d}^{\prime}$ for the month of May equals $45.5 \mathrm{~m}^{3} /$ day which is by $13.75 \%$ higher than the daily required amount of water $Q_{d}$ $=40 \mathrm{~m}^{3} /$ day. This complies with the standard IEC 62253 [12] and confirms the required accuracy of the proposed procedure. Therefore, there is no need to redesign the PV generator.

Finally, based on the prices that can be found in the internet (at www.windandsun.co.uk), the present worth of costs $\left(C_{P W}\right)$ in USD for the considered PV water pumping system is estimated using the following formula [30], [36]

$$
C_{P W}=C_{i}+F_{P W} \times C_{o m}-S V \times\left(\frac{1}{1+D R}\right)^{L S},
$$

where $C_{i}=16350.43$ USD is the initial cost of the off-grid PV water pumping system, which is calculated by adding the costs of individual system components $\left(C_{I S C}=\right.$
11678.88 USD) along with the installation and balance of system costs $\left(C_{B O S}=0.4 \times C_{I S C}\right) ; C_{o m}=0.02 \times C_{i}$ is the operation and maintenance cost in USD; $S V=0.1 \times C_{i}$ is the scrap value in USD; $L S=25$ years is the expected lifespan for the off-grid PV water pumping system; and $D R=0.0755$ (or $7.55 \%$ ) is a dimensionless discounting factor. The initial costs are calculated excluding costs for the diesel-powered electric generator, piping, water tank, and float switch for water level detection in the water tank, while tax $(20 \%)$ and delivery $(5.4 \%)$ charges are included. In addition, $F_{P W}=$ 11.098 stands for the present worth factor (dimensionless) whose value is determined by means of

$$
F_{P W}=\frac{(1+D R)^{L S}-1}{D R \times(1+D R)^{L S}} .
$$

Thus, the present worth of costs $C_{P W}$ estimated using (45) equals 19715.56 USD. The value of $C_{P W}$ is lower than the one reported in [30], which could be expected for one offgrid PV water pumping system with a lower installed capacity and the $1.7 \mathrm{~kW}$ BLDC motor instead of an induction motor.

\section{CONCLUSIONS}

The main conclusions that can be drawn from the presented results and discussion are:

1. The proposed procedure was successfully validated and showed a high level of accuracy. It is new, quick and innovative, it can be easily implemented in practice, and it resulted in a number of design engineering benefits.

2. The application of the Sivkov empirical model resulted in overestimations of available solar energy (in average by about $20 \%$ ) and electricity generation (in average by about $5.5 \%$ ) at the considered site, but there was no need to redesign the PV generator (which in both cases consists of $18 \mathrm{PV}$ modules).

3. The daily water production for the month of May having the lowest GNI value in the irrigation season is by $13.75 \%$ higher than the daily required amount of water (of $40 \mathrm{~m}^{3} /$ day). This confirmed that the proposed procedure is in line with the standard IEC 62253 [12].

4. Both the proposed procedure and the software LORENTZ COMPASS gave the final design solution consisting of the same components.

5. It is shown that parameters, such as the data collection period and data availability, can affect the values of meteorological variables used in the design procedure of the off-grid PV water pumping systems. Accordingly, it is recommended that the data collection period should be equal to or longer than 20 years, and that the data availability should not be less than $70 \%$.

6 . It is found that there are significant differences between the values of meteorological variables, which can be taken from various meteorological online services. 7. It is also found that the present worth of costs for the considered PV water pumping systems is 19715.56 USD, excluding costs for the diesel-powered electric generator and piping. 


\section{ACKNOWLEDGMENT}

The authors would like to thank Mr. Miroslav Mićić, M.Sc.C.E. from the company Turn-Key Project d.o.o., Belgrade, Serbia (https://kpenergy.com/kontakt/) for providing the photographs shown in this paper and additional information about the Solar Pumping Project: Požarevac 3.5ha Trešnja.

\section{CONFLICTS OF INTEREST}

The authors declare that they have no conflicts of interest.

\section{REFERENCES}

[1] M. Mićić, "Solar Pumping Project: Požarevac 3.5ha Trešnja", Belgrade, Serbia, Turn-Key Project d.o.o., 2019. [Online]. Available: https://www.tkpenergy.com/wpcontent/uploads/2019/12/Projekat_PS2-1800_35-hektara-4-sekcijetre\%C5\%A1nja_Pozarevac_35m_42cbm_2880Wp.pdf

[2] S. Alsadi and T. Khatib, "Photovoltaic power systems optimization research status: A review of criteria, constraints, models, techniques, and software tools", Appl. Sci., vol. 8, article ID 1761, 2018. DOI: 10.3390/app8101761.

[3] S. M. A. Ibrahim, H. H. El-Ghetany, and A. G. M. Shabak, "Comprehensive design tool for sizing solar water pumping system in Egypt”, Appl. Sol. Energy, vol. 56, no. 1, pp. 18-29, 2020. DOI: 10.3103/S0003701X20010053.

[4] W. H. Habeeb, "Design and implementation of photovoltaic-water pumping system for use in Iraq", Journal of Engineering and Sustainable Development, vol. 22, no. 6, pp. 141-151, 2018. DOI: 10.31272/jeasd.2018.6.12.

[5] C. Tiba and E. M. de S. Barbosa, "Softwares for designing, simulating or providing diagnosis of photovoltaic water-pumping systems", Renewable Energy, vol. 25, no. 1, pp. 101-113, 2002. DOI: 10.1016/S0960-1481(00)00172-5.

[6] T. Huld, "PVMAPS: Software tools and data for the estimation of solar radiation and photovoltaic module performance over large geographical areas", Solar Energy, vol. 142, pp. 171-181, 2017. DOI: 10.1016/j.solener.2016.12.014.

[7] N. Paulescu, N. Stefu, D. Calinoiu, E. Paulescu, N. Pop, R. Boata, and O. Mares, "Ångström-Prescott equation: Physical basis, empirical models and sensitivity analysis", Renewable and Sustainable Energy Reviews, vol. 62, pp. 495-506, 2016. DOI: 10.1016/j.rser.2016.04.012.

[8] D. T. Cotfas, P. A. Cotfas, E. Kaplani, and C. Samoila, "Monthly average daily global and diffuse solar radiation based on sunshine duration and clearness index for Brasov, Romania", Journal of Renewable and Sustainable Energy, vol. 6, article ID 053106, pp. 116, 2014. DOI: $10.1063 / 1.4896596$.

[9] R. F. Mechlouch and A. B. Brahim, "A global solar radiation model for the design of solar energy systems", Asian Journal of Scientific Research, vol. 1, no. 3, pp. 231-238, 2008. DOI: 10.3923/ajsr.2008.231.238

[10] A. Mahjoubi, "Global solar radiation in two Tunisian cities: Comparison of prediction and measured data", Journal of Sustainable Energy, vol. 9, no. 2, pp. 69-76, 2018.

[11] M. G. Iziomon and H. Mayer, "Assessment of some global solar radiation parameterizations", Journal of Atmospheric and SolarTerrestrial Physics, vol. 64, no. 15, pp. 1631-1643, 2002. DOI: 10.1016/S1364-6826(02)00131-1.

[12] Photovoltaic Pumping Systems - Design Qualification and Performance Measurements, IEC Standard 62253:2011, 2011.

[13] Photovoltaic Devices - Procedures for Temperature and Irradiance Corrections to Measured I-V Characteristics, IEC Standard 60891:2009, 2009.

[14] Photovoltaic Devices - ALL PARTS, IEC Standard 60904:2020 SER, 2020.

[15] Solar Powered Water Systems - Design and Installation Guide, UNICEF Water Mission, 2020. [Online]. Available: https://www.pseau.org/outils/ouvrages/unicef_water_mission_solar_p owered_water_systems_design_and_installation_guide_2020.pdf

[16] T. M. Pavlović, D. D. Milosavljević, A. R. Radivojević, and M. A. Pavlović, "Comparison and assessment of electricity generation capacity for different types of PV solar plants of 1MW in Soko Banja
Serbia", Thermal Science, vol. 15, no. 3, pp. 605-618, 2011. DOI 10.2298/TSCI1 10322065P

[17] A. Hadj Arab, M. Benghanem, and A. Gharbi, "Dimensionnement de systèmes de pompage photovoltaïque", Revue des Energies Renouvelables, vol. 8, no. 1, pp. 19-26, 2005.

[18] Solo Line 36/10 - $160 \mathrm{~W}$ : Mono- and polycrystalline module family, Luxor Solar GmbH, Stuttgart, Germany, 2020. [Online]. Available: https://www.europe-solarstore.com/download/luxor/lx_sololine_datas heet.pdf

[19] Chapter 8 - Measurement of Sunshine Duration, Part I. Measurements of Meteorological Variables, in WMO Document No. 8: Guide to Meteorological Instruments and Methods of Observation, 7th ed., World Meteorological Organization (WMO), Geneva, Switzerland, 2008. [Online]. Available: https://library.wmo.int/doc_num.php?explnum_id=3154

[20] PS2-1800 C-SJ5-12 Solar Submersible Pump System for 4" Wells, Bernt Lorentz GmbH \& Co. KG, Henstedt-Ulzburg, Germany, 2017. [Online]. Available: https://lorentzpumps.co.za/wp-content/uploads/ 2017/10/PS2-1800-C-SJ5-12-1.pdf

[21] B. Marion and B. Smith, "Photovoltaic system derived data for determining the solar resource and for modeling the performance other photovoltaic systems", Solar Energy, vol. 147, pp. 349-357, 2017. DOI: 10.1016/j.solener.2017.03.043.

[22] B. Perovic, D. Klimenta, M. Jevtic, and M. Milovanovic, "A transient thermal model for flat-plate photovoltaic systems and its experimental validation", Elektronika ir Elektrotechnika, vol. 25, no. 2, pp. 40-46, 2019. DOI: 10.5755/j01.eie.25.2.23203.

[23] A. Kimber, L. Mitchell, S. Nogradi, and H. Wenger, "The effect of soiling on large grid-connected photovoltaic systems in California and the southwest region of the United States", in Proc. of The IEEE 4th World Conf. on Photovoltaic Energy, Waikoloa, HI, USA, 2006, pp. 1-7. DOI: 10.1109/WCPEC.2006.279690.

[24] P. Nepal, "Effect of soiling on the PV panel kWh output", M.S. thesis, Delft University of Technology, Delft, the Netherlands, 2018.

[25] M. Abderrezek and M. Fathi, "Effect of dust deposition on the performance of thin film solar cell", Elektronika ir Elektrotechnika, vol. 24, no. 1, pp. 41-45, 2018. DOI: 10.5755/j01.eie.24.1.20158.

[26] D. T. Cotfas, P. A. Cotfas, and O. M. Machidon, "Study of temperature coefficients for parameters of photovoltaic cells", Hindawi International Journal of Photoenergy, vol. 2018, article ID 5945602, pp. 1-12, 2018. DOI: $10.1155 / 2018 / 5945602$.

[27] N. Anani and H. Ibrahim, "Adjusting the single-diode model parameters of a photovoltaic module with irradiance and temperature", Energies, vol. 13, no. 12, article ID 3226, pp. 1-17, 2020. DOI: $10.3390 /$ en 13123226 .

[28] S. Borekci, E. Kandemir, and A. Kircay, "A simpler single-phase single-stage grid-connected PV system with maximum power point tracking controller", Elektronika ir Elektrotechnika, vol. 21, no. 4, pp 44-49, 2015. DOI: 10.5755/j01.eee.21.4.12782.

[29] R. Ndegwa, E. Ayieta, J. Simiyu, and N. Odero, "A simplified simulation procedure and analysis of a photovoltaic solar system using a single diode model", Journal of Power and Energy Engineering, vol. 8, no. 9, pp. 65-93, 2020. DOI: 10.4236/jpee.2020.89006.

[30] A. Al-Badi and H. Yousef, "Design of photovoltaic water pumping system as an alternative to grid network in Oman", Renewable Energy and Power Quality Journal (RE\&PQJ), no. 14, pp. 11-15, 2016. DOI 10.24084/repqj14.203.

[31] PS1800 Centrifugal Pumping Systems, Bernt Lorentz GmbH \& Co. KG, Henstedt-Ulzburg, Germany, 2017. [Online]. Available: https://www.technosun.com/descargas/LORENTZ-PS1800-HR-Ctablas-de-dimensionamiento-EN.pdf

[32] Sh. Biswas and M. T. Iqbal, "Dynamic modelling of a solar water pumping system with energy storage", Hindawi Journal of Solar Energy, vol. 2018, article ID 8471715 , pp. 1-12, 2018. DOI: $10.1155 / 2018 / 8471715$.

[33] A. Purna Chandra Rao, Y. P. Obulesh, and Ch. Sai Babu, "Mathematical modeling of BLDC motor with closed loop speed control using PID controller under various loading conditions", $A R P N$ Journal of Engineering and Applied Sciences, vol. 7, no. 10, pp. 1321-1328, 2012

[34] S. Pindado and J. Cubas, "Simple mathematical approach to solar cell/panel behavior on datasheet information", Renewable Energy, vol. 103, pp. 729-738, 2017. DOI: 10.1016/j.renene.2016.11.007.

[35] E. Skoplaki and J. A. Palyvos, "On the temperature dependence of photovoltaic module electrical performance: A review of efficiency/power correlations", Solar Energy, vol. 83, no. 5, pp. 614- 
ELEKTRONIKA IR ELEKTROTECHNIKA, ISSN 1392-1215, VOL. 27, NO. 2, 2021

624, 2009. DOI: 10.1016/j.solener.2008.10.008

[36] A. Singh, "Techno-economic feasibility study of solar water pumping for public facilities in Nigeria", M.S. thesis, Humboldt State University, Arcata, CA, USA, 2019.

This article is an open access article distributed under the terms and conditions of the Creative Commons Attribution 4.0 (CC BY 4.0) license (http://creativecommons.org/licenses/by/4.0/). 